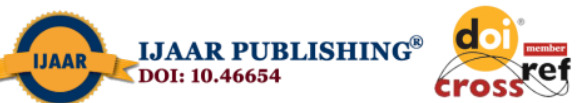

International Journal of Advanced Academic Research (Arts, Humanities and Education) | ISSN: 2488-9849

Vol. 6, Issue 5 (May, 2020) |www.ijaar.org

\title{
ENTREPRENEURSHIP EDUCATION: A REMEDY TO YOUTH UNEMPLOYMENT IN NIGERIA
}

\author{
AKINPADE OYEJOKE ADUNOLA \\ Department of Curriculum and Instructions \\ School of Education, \\ The College of Education, Lanlate \\ 07067212225 \\ akinpadeoyejokeaduola@gmail.com
}

\begin{abstract}
In a developing nation, entrepreneurship education has been and would likewise continue to be a great economic stimulation to serve as a remedy to the youth unemployment in Nigeria. This paper focused on entrepreneurship education as a remedy to youth unemployment. Some issues discussed include the youth unemployment, causes of youth unemployment, effects of youth unemployment, the concepts of entrepreneur, importance of entrepreneurship education as a remedy to youth employment, as well as often encountered challenges of entrepreneurial education and the strategies/solutions for effective entrepreneurship education. On the basis of these and other auxiliary discourses, conclusion was reached and recommendations were raised for consideration. These include a call for all stakeholders to allow the entrepreneurship education to reach out to the youth, regardless of theirethnic, cultural, religious, geographical or political affiliations by establishing good scheme aimed at encouraging youths to spend their free times positively. Finally, government should create friendly, social political and economic environments so as to encourage investors in entrepreneurial ventures with good financial assistance and motivation.
\end{abstract}

Keywords: Remedy, challenges, entrepreneurship education, youth, unemployment 


\section{Introduction}

Youths constitute the most significant part of the world population. They are the most active, diligent, creative, contributive and innovative group in any field of life but the irony of it is that a large portion/number of them around the world are unemployed and they cannot find any suitable job (Chapman, weather burn, Chilvers and Rousel, 2002). Youth unemployment has been an increased trend for many years not only in the developing countries but in the developed ones. According to ILO (2007), the increase in the number of youths that are getting secondary and tertiary education is a positive development; however, labour markets in many countries are unable to accommodate the expanding pool of these skilled young graduates through entrepreneurship education.

Unemployment has become a big issue in our society. It is a global phenomenon. Its effect can be felt socially, economically and psychological. The time between 16 and 24 is a crucial developmental life phase during which some major life tasks are expected to be attempted or commenced. Psychological development, social transactions and changes in status are closely related. The youth are expected to establish a sense of personal identity and become progressively more independent of parents because they move from school or via further education or training. Many of the young people leave home during the years to form households of their own with or without others. The majority of them form intimate relationship with non-family members.

\section{Youth Unemployment: The Nigeria Situation}

In Nigeria, the accurate unemployed numbers are difficult to access, because every year new graduates from our higher institutions of learning join the unemployed number due to inadequate job opportunity. Unemployment situation can be grouped into two categories;

1. The older unemployed who lost their job because of retrenchment, bankruptcy or redundancy.

2. The younger unemployed most of who have never been employed.

According to Awogbenle \& Iwuimadi (2010), the statistics figure from the Manpower Board and the Federal Bureau of statistics (2010) shows that Nigeria has youth population of above 85 million, representing $63 \%$ of the total population of the country. Moreso, 64 million of them are unemployed while 1.7 million are under-employed. The 1990-2010 data on youth unemployment showed that the largest group of the unemployed people is the secondary school graduates.

Likewise, $42 \%$ of the employment rate is among urban youths aged 15-19. Also, two third of the urban unemployed are ranged from 16-25 year old. The author however admitted that there is no consistent trend of accurate number of unemployment rate/figure in Nigeria.

The following are some of the suggested causes of youth unemployment especially in Nigeria and other developing countries.

1. Job Search/Seekers: Many of the youths are always changing their jobs thereby searching for jobs frequently. They have refused to utilize the knowledge acquired in the courses of their training in tertiary institutions to create jobs.

2. The second one is the rapidly growing urban labour force arising from rural-urban migration which is usually explained in terms of push pull factors including the pressure resulting from man-land ratio in the rural area and the existence of serious 
underemployment arising from the seasonal cycle of climate and inadequate infrastructural facilities which make the rural lifefor people to therein.

3. Population Growth: World population is on the increase, especially in the third world. Many people are not creating jobs but looking for white collar jobs which are few compared to the number of those hustling for them.

4. The school curriculum is inadequate. The outdated school curricular and inadequate employable skills have made some scholars and commentators to have argued that as far as the formal sector is concerned, the average Nigerian graduates are not employable and therefore do not possess the skills needed by the employees of labour for a formal employment. Since subjects that could lead the youth to vocational related employment such as handwork craft and natural study which could lunch them into the areas of vocational interest, have been excluded in the curriculum. These subjects had helped a lot of drop outs in the last three decades to find their feet in the area of employment.

5. There is malfunctioning of educational system, that is, it is not addressing the pertinent needs of young people nor the labour market demand. Unfortunately, the education of many youths my not provide them the jobs they are searching for.

6. Under-development in the third world is another cause of unemployment. Development will surely lead to jobs creation if the rural areas are developed, there will be jobs for the capable and interested people rather than moving to the urban centres making such places congested and filled with criminals.

7. Poor quality of education: In some cases, poor quality of education bring about a mismatch between the school and the labour market and, in case of school drop outs, they are not employable. There are other such drop outs who could explore areas that are not strictly for professionals.

8. The retirement age is not favourable for the youth. The old people do not want to leave their offices. To crown it all, the government compound the problem by increasing retirement age. When it is not reviewed, people falsify their age at the point of entering labour market, thereby staying too long on the jobs and forestalling the youths from taking up such post, while some replace themselves with their children.

9. Awogbenle \& Iwuimadi (2010) say that there is no vibrant manufacturing sector which has the capacity to absorb unemployed youths in Nigeria. There are over 800 collapsed industries in Nigeria and over 39 factories closed up in 2009, while about half of the remaining operating firms have been classified as 'ailing' a situation that poses a great threat to the survival of manufacturing in the next few years.

10. Information and Communication Technology is another cause of unemployment. As good as it is technologically, jobs that are meant for five people technology can be done by just one person because it is a matter of machine operation. Unfortunately, more jobs are not being created to cause a balance between technology and labour demand.

11. There is no adequate counseling for the youths while in training or school. Some parents even force the wards into what they do not enjoy doing or have ability in, just because they want their wards to keep up the family business or professional office. Likewise, some children blindly select subjects because they want to be like their friends. In most cases, the abilities of such students may not be commensurate with their interest. The issue of massive corruption that is perpetuated and still being perpetuated on daily basis by the military and civilian administrations is also there. Corruption has robbed the country of developing a vibrant economic. 
12. Many of our youths lack shitake qualification. Young people without skills are more likely to be unemployed. However, the service sector has increase in importance and created unskilled jobs such as supermarkets' check-out cashiers and waiters.

13. Nigerian government policy on minimum wage is inconsistent. Increase in minimum wage can lead to retrenchment, making especially youths who are just entering the world of work to lose their job and become employed.

\section{Effects of Youth Unemployment}

The youth unemployment can be grievous, it affects the individual lives of jobless youth but the effects transcend the individuals. The education, economic, social and health effects of youth unemployment affect society on a macro level. Unemployment affects not only those out of work but their families as well. It has both obvious and subtle effects on individuals, communities, families, business and political entities. The following are some of the effects of youths' unemployment.

(i) It can lead to increased vulnerability of young people making them take to drugs and crime.

(ii) Youth unemployment can generate frustration and low self-esteem.

(iii) Youth unemployment can also expose them to greater risks of lower future wages, repeated periods of unemployment, longer unemployment spells as adult and income poverty.

(iv) Youth may not be accorded recognition meant for them, just as the women are said to have been marginalized in so many areas.

(v) It can impose large economic cost on the society and the public will bear the brunt. Youths unemployment will surely not force them out of the society, they will continue to consume and not contribute to the economy but living at the expense of the public.

(vi) A very covered government that tries to package training programmes may not be successful, especially when the unemployed youths are numerous.

According to WHO (2011), health is a state of complete physical, mental and social well-being and not merely the absence of disease or infirmity. Unemployed people are often not in good frame of mind because something important is lacking in their lives. Unemployed youth that has no money cannot think of marriage talk less of having children, because he/she lacks the resources. The society usually perceives the unemployed youth as useless and unproductive.

The adequate income generally means being dependent on others, friends, relatives, family, a partner or the state. They are faced with financial problems. Most of youths are jobless and the few that have jobs are not well paid, as a result, they have no assets to sustain them at crucial time. Reference to the current global high cost of living, unemployed youth will be in abject poverty. From researches, it has been found that there is a correlation between unemployment and crime and that joblessness is a major motivator of engaging in theft, burglary and violent crimes (Dickinson, 1995). The unemployed youth have also been linked with murder and suicide (Sampson, 1987 \&Papps, 1999).

\section{The Concept of Entrepreneur}

Adeniran(2020) citing Hisrich and Peter (2012), sees an entrepreneur in as an actor and individual who engages in controlling large scale project while in the tenth century an entrepreneur was seen as an individual who bears the risk of yield or loss in a fixed price 
pact with the government. Adeniran (2020) sees entrepreneur as a person who harmonies controls and systematizes the process of production in order to make the supreme output at lowest cost thereby making profits. He/she is the Chief Executive or Managing Director Officer in an executive office.

\section{Definitions of Entrepreneurship Education}

In Nigeria, entrepreneurship education has been identified as a major means of assisting our youth and adults to attain desired skills and capacities to be self-reliant or selfemployed and minimize youth unemployment.

\section{Objective of Entrepreneurship}

Entrepreneurship Education is oriented towards different ways of realizing privileges. This is what makes entrepreneurship education distinctive in its forms on realization of opportunity. Entrepreneur education is focused on the best way of operating existing hierarchies (Ojeifo, 2013).

- To serve as a catalyst for economic growth and development.

- To reduce high level of poverty, create jobs create smooth transition from traditional to a modern industry economy.

- To offer functional education for the youths that will encourage them to be self-employed and reliant.

- To provide the youth graduates with adequate training that will enable them to be creative innovative in identifying novel business opportunities.

- To reduce rural-urban migration.

- To offer tertiary institution graduates with adequate training in risk management in order to make certain bearing feasible.

- To inculcate the spirit of perseverance in the youths and adults which will enable them to persist in any business venture they embark on.

- To create smooth transition from traditional to a modern industrial economy.

\section{Characteristics of an Entrepreneur}

Adeniran (2020) highlighted some of qualities that characterize an entrepreneur such as: job orientation, leadership, self-confidence, risk taking, and drive and energy.

\section{Types of Entrepreneur}

Adeniran (2020) classified entrepreneurs into Fabian and Drone entrepreneurs.

\section{Importance of Entrepreneurship Education as Remedy to Youths Unemployment}

Entrepreneurship is a key driver of our economy in Nigeria, wealth and a high majority of jobs are created by small scale businesses started by entrepreneur usually minded individuals, many of whom go on to create big businesses. This is more creative freedom for people who are exposed to entrepreneurship education.

Entrepreneurship education is an attribute that enables a person to identify business opportunities, together with capacity to organize needed resources with which to profitably take advantage of such opportunities in the face of calculated risks and uncertainty (Ayinde, 2008). 
- Job generation: Unemployment is a major issue facing all nations of the world and solving this issue is the quest of all nations. Entrepreneurship has remained the most relevant equipment for solving youths unemployment problem/issues/challenges. Ikwuaku (2001) opined that who take to entrepreneurship immediately, succeed in providing jobs for themselves, as well as other nations.

- Income generation: Onuoha (2005) says that the existence of entrepreneur ino an economy will give room for increase in taxation which will encourage the government to save, earn revenue as well as provide basic amenities such as school, pipe borne water, electricity, hospital, police station, local government headquarters for the populace.

- Transfer of technological facilities: Osano\&Koine (2016) claim this prospect for developing and employing suitable technological approaches is given by entrepreneurs for the sustainability of youth in our society and reduce youths unemployment.

Increase in Productivity through Innovation: Innovation is the creation of better or more effective products, processes, technology and ideas which aid comfort convenience and efficiency in everyday life. So is the means by which entrepreneur convert ideas into marketable solution. Innovation has to do with changes leading to improvement in the quality and quantity of products and processes. In other words, innovation is dynamic

- Increase in resource utilization: Resources, both human materials and non-human materials could be left fallow, but entrepreneurs harness these resources which otherwise remain idle and put them into productive and profitable use. They contribute to the mobilization of local resources including human resources (Adeniran, 2020).

- Encouragement of large-scale creativities and public enterprises: Entrepreneurs as the key factors of production principally produce raw materials in the form of some processed goods for the use of largest/biggest enterprises.

- Effective and competent use of individual potentials and energies: Most successful jobs today in Nigeria started small. Entrepreneurship is making individual to use their potential and energies to create wealth, independence and status in society.

- Stimulation of growth: The work of entrepreneur in large and small scale enterprises encourages the diversification and sustenance of the economy.

\section{Challenges of Entrepreneurial Education for Youths Unemployment}

According to the National Bureau of Statistics (2007), the entrepreneurship development programmes instituted by the beneficiaries of such programmes are still low when compared to the spiraling level of youth unemployment.

- Learners Orientation: Place of passion is critical in cultivating and promoting entrepreneurship that may end up taking the course as a career goal.

- School Administrator Orientations: At present, many school administrators are yet to appreciate the value of potential of entrepreneurship education in the development of the nature and reduce youths unemployment

- Inadequate Teaching Facilities: The necessary materials to aid the teaching and learning process of entrepreneurship in Nigeria's higher institutions of learning are not adequately available.

- Poor access to vocational skills-development training for rural and urban youths involved in the informal economy.

- Rampant political and bureaucratic corruption together with the absence of social consensus on important macro-economic policy issues. 
- Inadequate Capital: No doubt, one of the biggest challenges of any entrepreneur is in adequate of capital because to get capital to start business is not so easy at all.

- Capacity Building Centre: Special centers for capacity building, where the intending entrepreneur is made to have hand-on experience are not adequate in Nigeria, if they ever exist. Incidentally, entrepreneurship is better being theoretical.

- Absence of regulatory mechanisms for effective oversight of enterprises development initiatives.

\section{Strategies/solutions for effective entrepreneurship education in solving youth's unemployment}

There is no problem without solution, no matter how difficult a problem is, it can be solved depending on the action taken. The investigator has proffered some possible ways to solve this problem such as follows:

(i) There should be some form of general school work based learning incorporated in some studies as part of the national economic development strategies. The development of apprentice scheme would give graduates work skills and experience.

(ii) Youths should be well trained and adequately equipped with entrepreneurship education to meet the demand of the labour markets. No doubt, reforms are going on in the education sector of Nigeria with a view of meeting the demands of the society such as introduction of free Compulsory Basic Education (UBE) for Nigerians and the licensing of private universities (Ijaya, 2007).

There should be relationship between curriculum and societal needs of the labour market. The curriculum should be constantly tailored on entrepreneurship education for solving youths unemployment because things are not static.

- Pool local public and private funds together to create a small venture capital fund.

- School based enterprises where students identify potential business, plan, create and operate small business using the school as mini incubators for the youth to solved unemployment.

- Provide small business school where interested student and community members can participate.

- Youths unemployment can be solved by developed entrepreneurship internship porgrammes matching students with locally successful entrepreneurs with clearly established education programmes.

- Improving on the government taxation on small scale business.

- Creating an economy friendly political environment.

- Establishing an enterprise college aimed at fostering the specific skills sets required for entrepreneurship to serve as skill acquisition centres for the youths in order to find solution to youths unemployment.

- Youths should be ready to learn, put in all it takes to study and stop cutting corners. If youths are not ready/prepare to learn and study hard, it leads to poor education without desirable benefits, rather it becomes demetrious/disadvantageous interested in it. If all they want in the city are available on farm/agric. settlements, agricultural will be more attractive to the youth in our society.

- The recent agitation of workers that the government should increase their years of services is unjustifiable. These workers have failed to realize that the longer they stay in service, the grievous the effect on employment of the youth. So reducing retirement age will allow the youth take their rightful place in the world of work. 
- Population explosion should be guarded; against population should be curtailed in such a way that families should give birth to a reasonable number of children which they can adequately train and cater for. There is no point having a large family size that one cannot provide for.

- Proper counseling should be given to youths while in school a regards the job they intend to do, interest must tally with the ability of the individual. The school counselors should make sure that the students do the relevant courses/subjects to the profession they entrepreneurship education the youths should be properly guided to see the advantages, hazards, benefits of such profession to avoid the problem of going in and out of a job but they should have a specific goal.

\section{Conclusion}

There is no contention that investment in our youths is investment in our future. Our youth unemployment is a menace in Nigeria and constitutes a real threat to nation's development. Early identification of embedded talents of an individual is very necessary for the proper planning of programmes for the manpower needs to the country, guiding unemployed youth to pursue the right type of entrepreneurship education through counseling in which the problem of unemployment will be solved with the introductions of learning. The youths may be lazy or they may not be focused. However, if the discussed solutions can be looked intoand implemented, employment will rise and unemployment problem will be drastically reduced.

\section{Recommendations}

The effects of unemployment on youth, their families, and society cannot be underestimated. Using entrepreneurship education to tackle the problem of youth unemployment will really do the country good as it will become a better place, a safer place and a country filled with talented and confident young men and women.

- The government should encourage entrepreneurship education to reach out to youths, regardless of their ethnic cultural, religious, geographical or political affiliations by establishing good scheme aimed at encouraging youths, to spend their free times positively.

- Government should create a conducive investment climate and business friendly environment through entrepreneurship education.

- Through entrepreneurship education, the youths should be encouraged not to rely only on white collar jobs alone. They should be ready to learn vocational jobs such as catering and so on. This can be done during and after school or on weekend basis.

- Entrepreneurship education should be enhanced for investment on human capital which should involve the youths. This means that improvement on entrepreneurship education, vocational skills training, health and nutrition employment opportunities, shelter and social services, directly address the problem of poverty and reduce crime among the youths.

- Nigerian government and other stakeholders must ensure that educational programmes across all levels of education are relevant so as to provide the youths and graduates with the necessary skills to go into entrepreneurship.

- Nigerian government should, in collaboration with financial institutions, provide motivation and encouragement to identifiable small scale entrepreneurs so as to promote quality and productivity to identifiable small scale. 
- Entrepreneurs should promote productivity and quality rather than shutting factories that are found to be producing sub-standard products.

- All stakeholders in education should support introduction of entrepreneurship education as compulsory course for all programmes of study in all higher institutions of learning.

- The society should be ready to assist government in entrepreneurial policy implementation. Community leaders should be counseled to be involved in spreading the good news of entrepreneurship education.

- Excursion programmes should be introduced from primary schools where students are taken round the society to observe and interact with a successful entrepreneur.

- Every stakeholder in education should support introduction of entrepreneurship education as a compulsory course for all programmes of study in all higher institutions of learning.

- The skills in entrepreneurship should be reactivated among students at all levels of education through intensive and articulated guidance and counseling services, thereby preparing them for the challenges of labour market. 


\section{Reference}

Adeniran, F. A. (2020). Challenges and Contributions of Entrepreneurship Education for Sustainable Development in Nigeria.In K.O. Usman, M.A. Abibola,S.O. Agbato\& S.J. Ogunkunle(eds.). Achieving Sustainable Development in Nigeria through Innovation Creativity and Entreprenurial Education.(pp 618-631).I badan.Peerless Grace Publishing.

Awogbemile, A. C. \&Iwumadi, K. C. (2010) Youth Unemployment: Entrepreneurship Development Programme as an Intervention Mechanism. African Journal of Business Management, 4 (6) 831-835.

Ayinde, O. E. (2008). Empirical Analysis of Agricultural Growth and Unemployment in Nigeria. African Journal of Agriculture Research, 3 (7), 465-468.

Chapman, B. D; Weatherburn, C. A., Chilvers, M. \&Roussel, S. (2002). Unemployment duration, schooling and property crime.Discussion paper, 447.Austrialian National University, Centre for Economic Research, Camberra.

Dickmsonn, D. (1995). Crime and unemployment despite tory denials there is a clear link between them. Public policy research 1995. Willey Online Library.

Hisrich, D. H. \& Peters, M. D. (2012).Entrepreneurship 5th edition McGraw Hill Higher Education.

Ikwuaku, C. N. (2001). Dimensions of development as measured by GNP human development index: Lagos Journal of Educational Administration and Planning, 1 (1) University of Lagos. Lucky Odoni Publishers.

ILO (2007). Youth in Crisis: coming of age in the 21st century.

Ojeifo, S. A. (2013). Entrepreneurship education in Nigeria: A panacea for youth unemployment. Journal of Education and Practice (6).

Onuoha, C. B. (2005). Fundamental of business and management in Nigeria $\left(3^{\text {rd }}\right.$ ed).OkigweAvan Global Publications.

Osano, H. M. \&Koine, P. W. (2016). Role of foreign direct investment on technology transfer and economic growth in Kenya: A case of energy sector. Journal of Innovation and Entrepreneurship, 5 (1), 31.

Papps, K. L. (1999). Unemployment and Crime: New evidence for an old question victory university of wellington.

Sampson, R. J. (1987). Urban black violence.The effect of male joblessness and family distribution.American Journal of Sociology.

WHY (2011). Mental Health Bulletin of the World Health Organization.Retrieved from the net on the 18th July, 2011. 